\title{
高速ゲート電圧制御による多並列MOSFET の損失均等化
}

\author{
正 員 奥田 達也* 非会員 角田 義一** \\ 非会員 浅井 孝公*** 非会員 浦壁 隆浩*
}

\author{
High-Speed Gate Voltage Control Method Equalizing Loss of Many Parallel MOSFETs
}

Tatsuya Okuda*, Member, Yoshikazu Tsunoda**, Non-member, Takamasa Asai**, Non-member,

Takahiro Urakabe*, Non-member

\begin{abstract}
It has been said that connecting MOSFETs in parallel makes power consumption reduce without concentrating current on one of MOSFETs easily, because the resistance of MOSFET have a positive temperature characteristic. But switching MOSFETs under low voltage and high current condition causes concentration of switching loss owing to unbalance of avalanche characteristics of MOSFETs and the concentration of switching loss leads a MOSFET to thermal destruction. In this paper, a novel gate drive circuit dividing the switching loss equally between MOSFETs connected in parallel is proposed. The surge energy at turn-off time is not consumed by the avalanche characteristic of MOSFETs, but by the channel resistance of the MOSFET, because the new circuit controls the gate voltage. The switching loss in the new circuit hardly increases compared to the conventional one, because its switches operate with a high-speed response.
\end{abstract}

キーワード : MOSFET, 並列接続, ゲート駆動回路, スイッチング損失, アバランシェ , 損失均等化

Keywords: MOSFET, Parallel Connection, Gate Drive Circuit, Switching Loss, Avalanche, Loss Equality

\section{1. まえがき}

近年需要か増えている低電圧・大電流定格の電力変換装 置では,定常損失を低減するため,オン抵抗の低い素子を使 用する必要がある。百ボルト以下の領域でよく使用される MOSFET は,オン抵抗が素子耐圧にほぼ比例するため,高効 率・低コスト化のためには，できるだけ低耐圧の MOSFET を使用する必要がある。

しかし , 低電圧・大電流定格の電力変換装置では寄生イ ンダクタンスに蓄積されるサージエネルギーが大きいため， スイッチング時に発生するサージ電圧が非常に大きくなる。 サージ電圧が MOSFET のアバランシェ電圧に達すると， アバランシェ破壊を誘発するため, サージ電圧をアバラン

\footnotetext{
$*$ 三菱電機 (株) 先端技術総合研究所

T 661-8661 尼崎市塚口本町 8-1-1

Advanced Technology R\&D Center, Mitsubishi Electric Corp.

8-1-1, Tsukaguchi-Honmachi, Amagasaki 661-8661

** 三菱電機 (株) 生産技術センター

干 661-8661 尼崎市塚口本町 8-1-1

Advanced Technology, Mitsubishi Electric Corp.

8-1-1, Tsukaguchi-Honmachi, Amagasaki 661-8661

*** 三菱電機エンジニアリング (株)

T 670-0993 姫路市千代田町 888 番地

Mitsubishi Electric Engineering Corp.

833, Chiyodachou, Himeji 670-0993
}

シェ電圧以内に抑える必要がある。アバランシェ破壊とは， MOSFET 内の寄生バイポーラトランジスタが動作し，局所 的な電流集中による局所加熱によって素子か破壞する現象 である(1)。光のため, 低電圧・大電流定格の電力変換装置 では, サージ電圧マージンを見込んだ耐圧の MOSFET を 使用し，オン抵抗は MOSFET を多並列接続することで低 減させる必要がある(2)(3)。

最近では,アバランシェ破壊耐量を向上し,サージエネル ギーを素子自身のアバランシェ特性によって吸収可能な素 子も製品化されている。しかし, 通常 MOSFET のアバラ ンシェ電圧の同一ロット内ばらつきは大きく, MOSFET を 多並列接続する場合, スイッチング時のサージエネルギー をアバランシェ特性で消費させると，アバランシェ電圧の 低い素子にサージエネルギーが集中し，並列素子間で損失 ばらつきが発生する。熱設計は損失の最も大きな素子を基 準にするため，全ての MOSFET の電流容量を最大限に利 用する事が出来なくなる。

本論文では, スイッチング時のサージエネルギーをアバ ランシェ特性で消費させた時に ,アバランシェ電圧ばらつき による損失集中についてシミュレーションを行い，損失集中 による素子の温度上昇を定量的に評価した。また，全ての MOSFET の電流容量を最大限に利用するため , スイッチン グ損失をほとんど増加させる事なく，サージエネルギーを 
多並列接続された MOSFET に均等分散できるゲート駆動 回路方式を提案した。これは，MOSFET のドレインーソー ス間電圧を検知し，サージエネルギーを MOSFET のチャネ ル抵抗で消費させる方式である。今回提案したゲート駆動 回路方式とアバランシェ方式のスイッチング損失を，実測 て評価した結果，本方式による損失均等効果により，損失集 中素子のスイッチング損失を $15 \%$ 低減することができた。

\section{2. アバランシェ電圧ばらつきによる損失ばらつき}

〈2. 1〉損失ばらつきの発生要因ＭOSFET を多並列 接続した場合，主に素子の才ン抵抗 $\left(\mathrm{R}_{\mathrm{DS}(\mathrm{ON})}\right)$ と素子のチャ ネル温度 (Tch) によって, 定常損失にばらつきが発生す る。また，素子のしきい值電圧 (Vth) , 素子の降伏 (アバラ ンシェ) 電圧 $\left(\mathrm{V}_{\mathrm{BR}}\right)$, 配線インピーダンス等の影響によっ て ,スイッチング損失にばらつきが発生する。本論文では， 素子のアバランシェ電圧ばらつき $\Delta \mathrm{V}_{\mathrm{BR}}$ によるスイッチン グ損失ばらつきについて検討する。

〈2.2〉同一ロット内ばらつき 定格 $75 \mathrm{~V} / 200 \mathrm{~A}$ の MOSFET のアバランシェ電圧の測定結果を图 1 に示す。 測定サンプル数は 48 個であり, 全て同一ロット内の MOSFET である。これより，同一ロット内におけるアバラン シェ電圧ばらつきは定格電圧の $10 \%$ 近い, 最大 $6 \mathrm{~V}$ となっ ている。

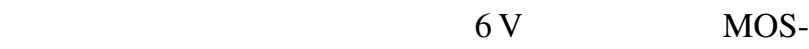
FET の , アバランシェ領域におけるドレインーソース間電圧 $\mathrm{V}_{\mathrm{DS}}$ とドレイン電流 $\mathrm{I}_{\mathrm{D}}$ の特性を図 2 に示す。具体的には $89 \mathrm{~V}$ のものと $94.9 \mathrm{~V}$ のものを選定している。図より，例 えばこれらの MOSFET を並列接続して $300 \mathrm{~A}$ のスイッチ ングをした場合，サージ電圧により $V_{\mathrm{DS}}$ は約 $98 \mathrm{~V}$ でクラ ンプされ，MOSFET1には MOSFET2 の倍近い電流が流れ ることになる。また，電流が $130 \mathrm{~A}$ 以下となる領域では， ほとんど全ての電流が MOSFET1 に流れる。このように， アバランシェ電圧の異なる MOSFET を並列接続した場合， アバランシェ領域の $\mathrm{V}_{\mathrm{DS}}-\mathrm{I}_{\mathrm{D}}$ 特性差によって電流アンバラ ンスが発生し，アバランシェ電圧の低い素子に損失が集中 する。

これまで, MOSFET のターンオフ損失について説明した が, 低電圧 $\cdot$ 大電流定格の電力変換装置では, ターンオン損 失はほとんど発生しない。これは, 低電圧·大電流定格の電 力変換装置では, 電源電圧に対する寄生インダクタンス発 生電圧の比率が大きく，ターンオン時の MOSFET の $\mathrm{V}_{\mathrm{DS}}$ にはほとんど電圧が印加されないためである。したがって 本論文ではターンオン損失は無視し，スイッチング損失は ターンオフ損失のみとして評価する。

〈2. 3〉 シミュレーション MOSFET を多並列接続し た時の，損失ばらつきについてシミュレーションを行う。 図 3 に,MOSFET を4並列接続し,誘導負荷を $42 \mathrm{~V} / 600 \mathrm{~A}$ でスイッチングさせた時のシミュレーション結果を示す。 シミュレーションではワーストケースとして ,アバランシェ 電圧の低い素子が一つだけ存在する場合を想定し，アバラ

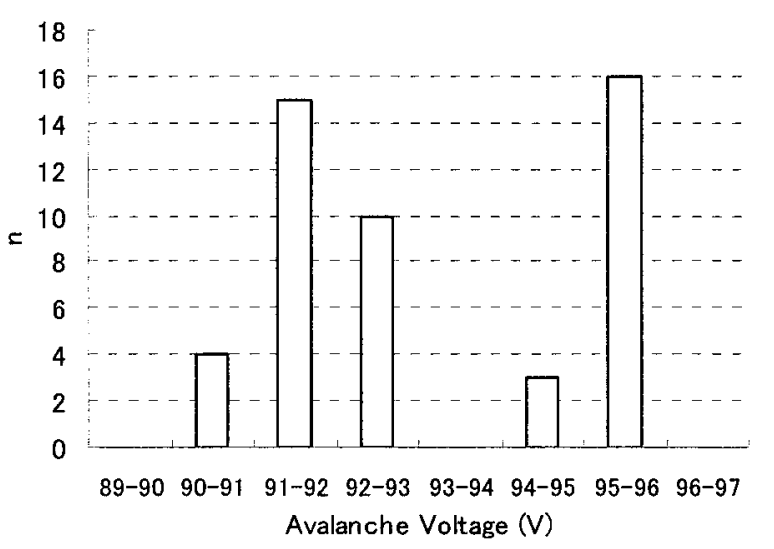

図 1 同一ロット内のアバランシェ電圧ばらつき

Fig. 1. Avalanche voltage dispersion in the same lot.

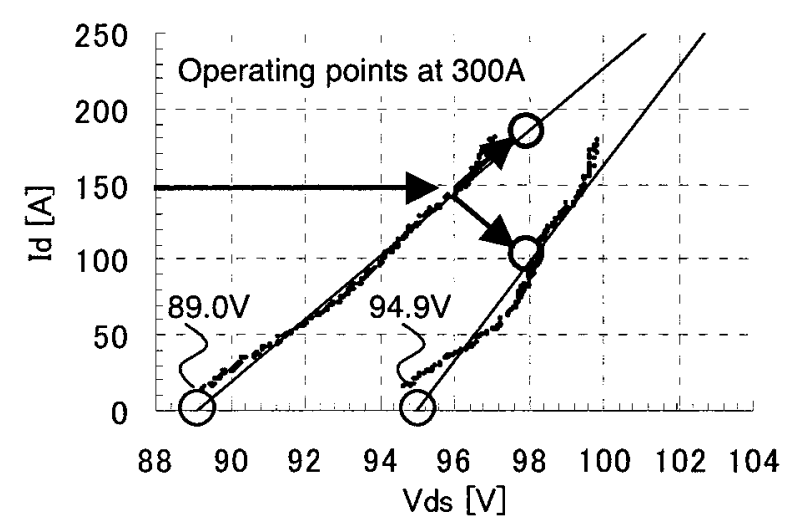

図 2 アバランシェ領域の $\mathrm{V}_{\mathrm{DS}}-\mathrm{I}_{\mathrm{D}}$ 特性

Fig. 2. $V_{D S}-I_{D}$ characteristics of avalanche domain.


図 3 ターンオフのシミュレーション結果

Fig. 3. Simulation result of turn off.

ンシェ電圧が $95 \mathrm{~V}$ の素子を 3 個 , $89 \mathrm{~V}$ の素子を 1 個とし た。図より，ドレインーソース間電圧 $\mathrm{V}_{\mathrm{DS}}$ がスイッチング サージによってアバランシェ電圧に到達すると電流アンバ ランスが発生し，アバランシェ電圧の低い素子に損失が集 


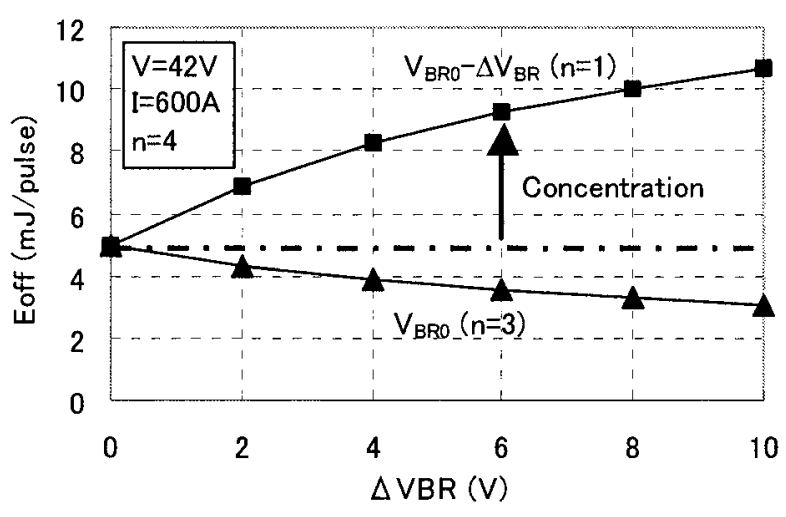

图 4 アバランシェ電圧ばらつきとターンオフ 損失

Fig. 4. Relationship of Avalanche voltage and loss of turn off region.

中する事が分かる。

図 4 に, アバランシェ電圧ばらつきを変えた時の，各素 子のターンオフ損失を示す。アバランシェ電圧ばらつきが 大きいほど, アバランシェ電圧の低い素子へのターンオフ 損失集中も大きくなる。例えば，アバランシェ電圧ばらつ きが $6 \mathrm{~V}$ あると，アバランシェ電圧が均一である場合と比 ベて，ターンオフ損失は 1.8 倍になる。

〈2.4〉 連続動作時における素子温度ばらつきの算定 MOSFET を 4 並列接続し, アバランシェ電圧の低い素子 が一つ存在する場合に, 各素子のジャンクション温度差が どのようになるのかを調べた。MOSFET のアバランシェ 電圧やオン抵抗は温度依存性を持っており，今回使用した MOSFET のアバランシェ電圧の温度係数は $0.08[\mathrm{~V} / \mathrm{K}]$, 才 ン抵抗の温度係数は $0.034[\mathrm{~m} \Omega / \mathrm{K}]$ であり，共に正の温度係 数であった。正の温度係数を持つと損失集中を緩和する方 向に働くため, 今回使用した MOSFET は, 温度ばらつき が比較的発生しにくい素子と言える。

图 5 に素子温度計算のフローチャートを示す。ある温度 条件 $\mathrm{Tj}(\mathrm{n})$ において, $\mathrm{R}_{\mathrm{DS}(\mathrm{ON})}$ で決まる電流分流より定常損 失を，各素子の $\mathrm{V}_{\mathrm{BR}}$ よりスイッチング損失を算出する。こ れらの素子損失による温度上昇 $\mathrm{Tj}(\mathrm{n}+1)$ を求め, $\mathrm{Tj}(\mathrm{n}+1)$ と $\mathrm{Tj}(\mathrm{n})$ の差か許容值以下となった時の值を解とした。

图 6 に計算結果を示す。計算条件として，雰囲気温度で のオン抵抗を $6[\mathrm{~m} \Omega]$,オンデューティーを 0.5 ,キャリア周 波数を $10[\mathrm{kHz}]$, 熱抵抗を $0.3[\mathrm{~K} / \mathrm{W}]$ とした。図より，ア バランシェ電圧ばらつきが大きいほどアバランシェ電圧の 低い素子の温度上昇は大きくなり，アバランシェ電圧ばら つきが $6 \mathrm{~V}$ あると，アバランシェ電圧が均一である場合と 比へて , 素子温度か喲 $10^{\circ} \mathrm{C}$ 高くなる。このように, ターン オフ損失を素子のアバランシェ特性で消費させると, ター ンオフ損失ばらつきによって，アバランシェ電圧の低い素 子のジャンクション温度が高くなってしまう。したがって， 全ての素子温度を均一にし，電流容量を最大限に利用する ためには, ターンオフ損失を均等化させる必要がある。

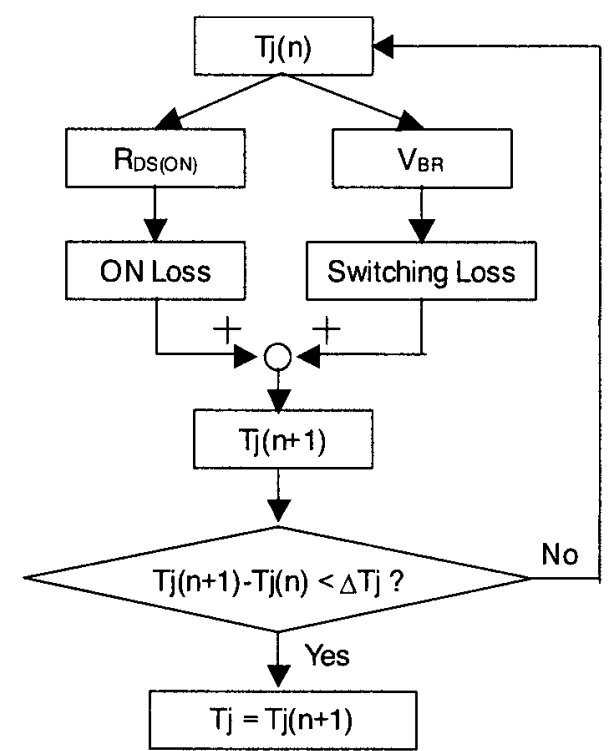

図 5 素子温度計算のフローチャート

Fig. 5. A flow chart of calculation for temperature of MOSFET.

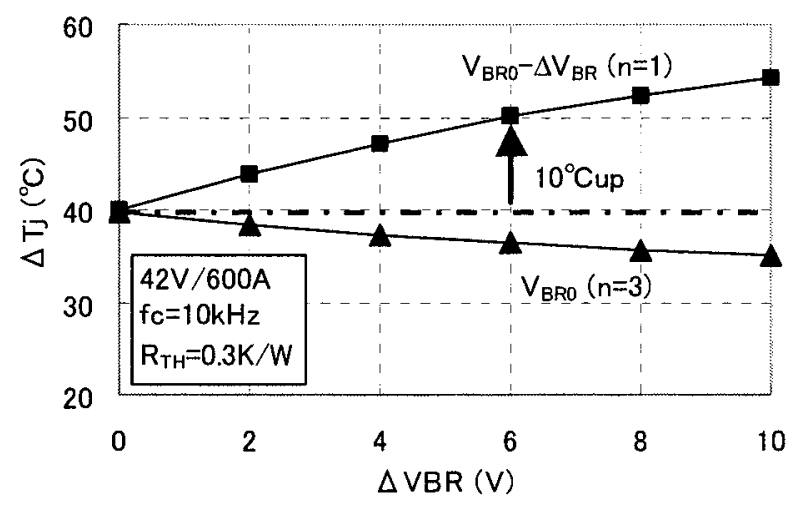

図 6 アバランシェ電圧ばらつきによる素子温度 上昇

Fig. 6. Channel temperature of MOSFET caused by avalanche voltage unbalance.

\section{3. 損失均等分散回路}

〈3. 1〉動作原理 上記課題を解決する手段として, ス イッチング損失をほとんど増加させる事なく , スイッチン グ損失を均等に分散させるための回路方式を検討した。こ れは, MOSFET のドレインーソース間電圧に忍じてゲート 抵抗を切り換えることで, ターンオフ時のサージエネルギー をアバランシェ損失ではなく，MOSFET のゲートで制御 されたチャネル抵抗で消費させる方式であり，スイッチン グ損失を均等に分散させることが可能である。また, サー ジエネルギーをチャネル抵抗で消費させる事で, アバラン シェ動作時のような素子内の電流集中現象による局所発熱 は発生しないため, MOSFET の信頼性も向上する。

提案するスイッチング損失均等分散回路を図 7 に, 動作 波形イメージを図 8 に示す。ゲートオフ抵抗には $\mathrm{R}_{\mathrm{G} 1}$ と 


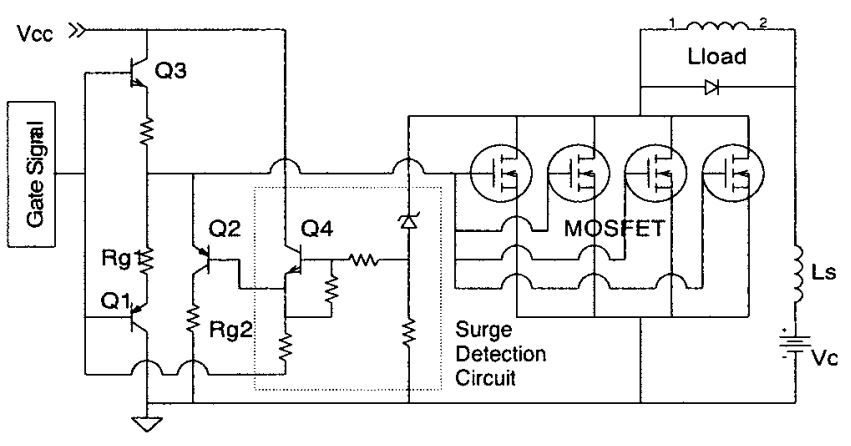

図 7 提案するゲート駆動回路

Fig. 7. Gate drive circuit of proposed gate drives.



図 8 ゲート駆動回路の動作波形イメージ

Fig. 8. Image of waveforms of a proposal gate drive circuit.

$\mathrm{R}_{\mathrm{G} 2}$ の二経路あり， $\mathrm{R}_{\mathrm{G} 1} \gg \mathrm{R}_{\mathrm{G} 2}$ となっている。ゲートオフ 信号が入力される区間 II では，Q1，Q2 がオン，Q3 がオ フすることで, MOSFET のゲート電荷を急速放電し , ゲー 卜電圧 $\mathrm{V}_{\mathrm{GS}}$ を低下させる。区間 III は損失均等分散回路の 動作遷移区間 (応答時間) で, サージ電圧によってドレイ ンーソース間電圧か設定電圧 $V_{\mathrm{SET}}$ を超えてから , サージ電 圧検知回路か動作し，Q2 をオフする区間である。サージ電 圧検出にはツェナーダイオードを用い, 光の検知電流を卜 ランジスタ Q4 で増幅することで，トランジスタ Q2 の才 ン/オフを制御している。区間 IV でトランジスタ Q2 がオ フすると，ゲート電流の通電経路が $\mathrm{R}_{\mathrm{G} 1}$ のみとなりゲート 電流が制限されるため, ドレイン電流の変化率か茚えられ， サージ電圧が抑制される。サージエネルギーが MOSFET のチャネル抵抗で消費され，サージ電圧か設定値以下にな ると再びQ2 がオンし , MOSFET のターンオフ動作が完了 する (区間 $\mathrm{V})$ 。

〈3.2〉応答時間とターンオフ損失の関係 図 9 に,ター ンオフ時のクランプ電圧とターンオフ損失の関係を示す。 シミュレーション条件は, 電源電圧 $42 \mathrm{~V}$, 負荷電流 $600 \mathrm{~A}$, 並列素子数 4 個, 配線の寄生インダクタンスは $60 \mathrm{nH}$ とし

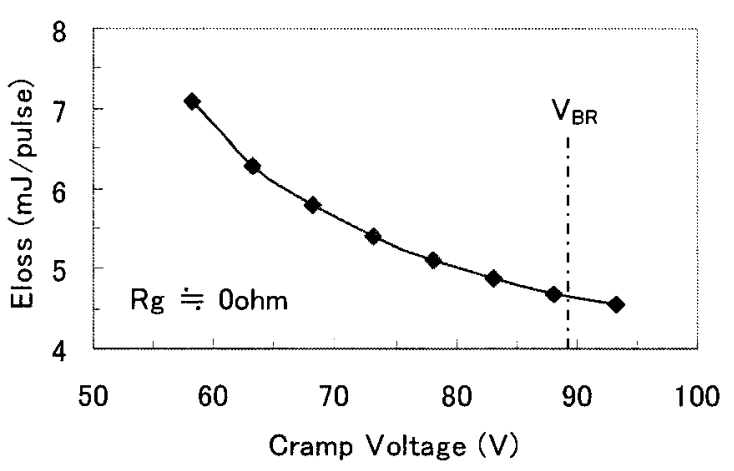

図 9 クランプ電圧とターンオフ損失の関係

Fig. 9. Relation between cramp voltage and turn-off loss.

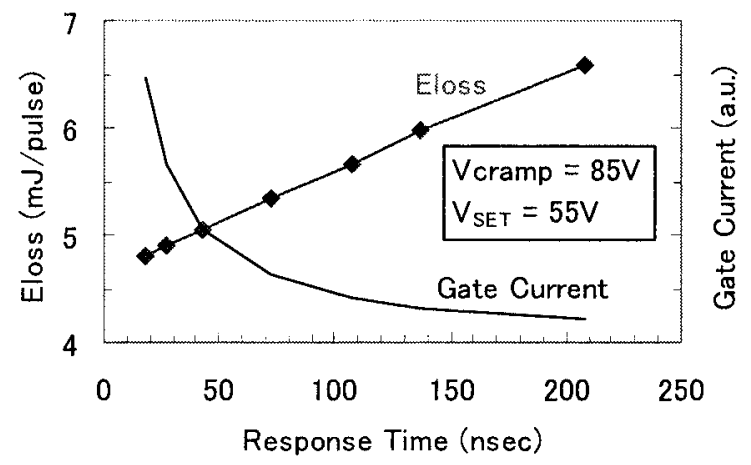

図 10 応答時間とターンオフ損失の関係

Fig. 10. Relation between response time and turn-off loss.

た。図より，クランプ電圧を低く設定するほどターンオフ 損失は増加するため, 損失を最小限に抑えるためには, ク ランプ電圧はアバランシェ電圧未満のできるだけ高い電圧 に設定するのか望ましい。

図 10 に,クランプ電圧を $85 \mathrm{~V}$, 設定電圧 $\mathrm{V}_{\mathrm{SET}}$ を $55 \mathrm{~V}$ とした時に，損失均等分散回路の応答時間とターンオフ損 失の関係を示す。図より，ターンオフ損失は損失均等分散 回路の応答時間に依存するため, ターンオフ損失を最小限 にするためには，損失均等分散回路の応答時間をできるだ け高速に動作させる必要がある。ターンオフ損失が応答時 間に依存する理由は以下である。応答時間が速い程，区間 $\mathrm{III}$ での $\mathrm{dV}_{\mathrm{DS}} / \mathrm{dt}$ を大きくできるため,ゲート抵抗 $\mathrm{R}_{\mathrm{G} 2}$ を小 さな值に設定できる。これにより，ゲート電荷を高速に引 き抜くことができ，区間 II 及び区間 III の時間を短縮化さ れるので，ターンオフ損失は小さくなる。

しかし，応答時間を速くするのは回路的に困難なだけで なく， $\mathrm{R}_{\mathrm{G} 2}$ を小さくする程ターンオフ時のゲート電流か増 加し, 特に応答時間が $50 \mathrm{nsec}$ 以下の領域ではゲート電流は 極端に増加する。ゲート電流の増加はトランジスタ Q1〜 Q4 の大型化・高コスト化の要因となる。以上より, ターン オフ損失の最小化とゲート電流の増加抑制のため, 損失均 等分散回路の応答時間を数十 nsec で高速動作させる事を目 標とした。 


\section{4. 実験結果}

〈4: 1〉 実験条件 定格 $75 \mathrm{~V} / 200 \mathrm{~A}$ の MOSFET を 4 並列接続し，誘導負荷を $42 \mathrm{~V} / 600 \mathrm{~A}$ でスイッチングさせ た時のターンオフ損失を評価した。また，同一ロット内の MOSFET を使用した時に，ターンオフ損失が最も集中する ワーストケースを想定し，表 1 に示す特性の MOSFET を 並列接続して評価した。

〈4 2〉 通常スイッチング 図 11 に, 外付けのゲート オフ抵抗をゼロとし，ターンオフ時のサージエネルギーを アバランシェ損失で消費させた時のターンオフ波形を示す。 図中， $\mathrm{V}_{\mathrm{DS}}$ は MOSFET のドレインーソース間電圧 , $\mathrm{V}_{\mathrm{GS}}$ は ゲートーソース間電圧 , $\mathrm{I}_{\mathrm{D}}$ は MOSFET1〜4のドレイン電流 である。ターンオフ時のサージ電圧が大きいため，MOSFET はアバランシェモードで動作しており， $\mathrm{V}_{\mathrm{DS}}$ は約 $96 \mathrm{~V}$ でクランプされている。アバランシェモードでの動作領域 では, アバランシェ電圧の低い素子 (MOSFET3) に電流 が集中しており，100 A 以下の領域では，ほぼ全ての電流 がMOSFET3に電流か流れている。

図 12 に,サージ電圧がアバランシェ電圧以内となるゲー トオフ抵抗を使用し ,サージエネルギーを MOSFET のチャ ネル抵抗で消費させた時 (Slow Switching 時) のターンオ フ波形を示す。図 10 のような極端な電流集中は見られな いが，しきい值電圧の低い素子 (MOSFET3) に若干電流 が集中している。また，ゲート抵抗が大きいため，スイッ チング速度が遅く，ターンオフ損失が大幅に増加している。

表 1 実験で使用した素子特性

Table 1. Device characteristics used in experiments.

\begin{tabular}{|c|c|c|}
\hline & $\mathrm{V}_{\mathrm{BR}}$ (DSS) & $\mathrm{Vth}$ \\
\hline MOSFET 1 & $94.9 \mathrm{~V}$ & $3.41 \mathrm{~V}$ \\
\hline MOSFET 2 & $94.9 \mathrm{~V}$ & $3.40 \mathrm{~V}$ \\
\hline MOSFET 3 & $89.0 \mathrm{~V}$ & $3.33 \mathrm{~V}$ \\
\hline MOSFET 4 & $95.0 \mathrm{~V}$ & $3.39 \mathrm{~V}$ \\
\hline
\end{tabular}

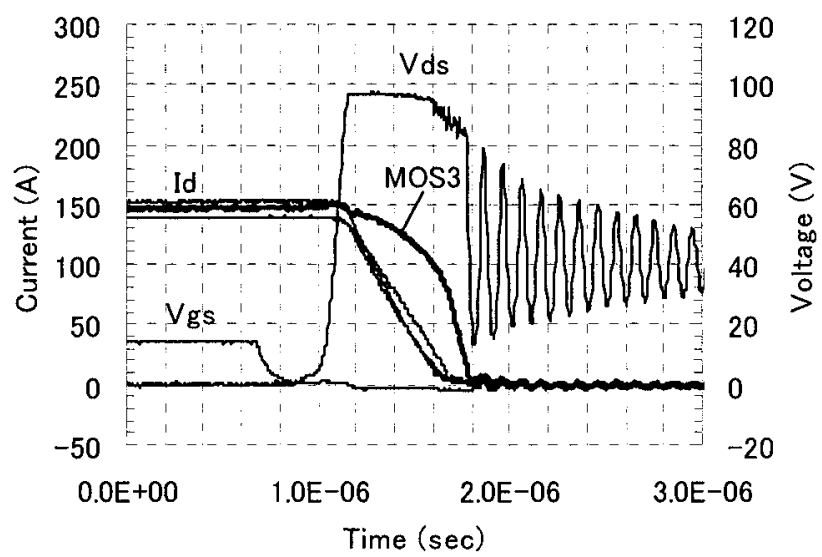

図 11 アバランシェモードでのターンオフ波形

Fig. 11. Turn off waveforms consuming surge energy with avalanche characteristics.
図 11 ,図 12 共に,素子特性か湔っている MOSFETにも 電流アンバランスが若干見られるが, アバランシェ発生時 も MOSFET としての動作時も同樣の大小関係 (MOSFET1 > MOSFET2 > MOSFET4) を示していることから，配線 インピーダンスの影響と考えられる。

〈4.3〉提案方式でのスイッチング 图 13 に,今回我々 か提案するスイッチング損失均等分散回路を使用した時の ターンオフ波形を示す。サージ電圧検知用のツェナーダイ オードには, 降伏電圧が $54 \mathrm{~V}$ のものを使用した。図より， ドレイン電圧が $75 \mathrm{~V}$ 前後に達するまでは $\mathrm{R}_{\mathrm{G} 1}$ と $\mathrm{R}_{\mathrm{G} 2}$ の 2 経路でゲート電荷を放電するため, ドレイン電圧が急速に 立ち上がり，高速なスイッチングが行われている。ドレイ ン電圧が 70〜 $80 \mathrm{~V}$ に達すると Q2 がオフするため $\mathrm{d} / \mathrm{dt}$ が 抑制され，サージ電圧もアバランシェ電圧 $(89 \mathrm{~V})$ 以内に 抑えられている。また，電流アンバランスは，しきい值電 圧の低い素子 (MOSFET3) に若干電流が多く流れている が, 配線インピーダンスによるアンバランスよりも小さい レベルである。

図 14 にターンオフ波形の拡大图を示す。図中， $\mathrm{I}_{\mathrm{total}}$ は MOSFET1〜4の全ドレイン電流である。これより，サージ

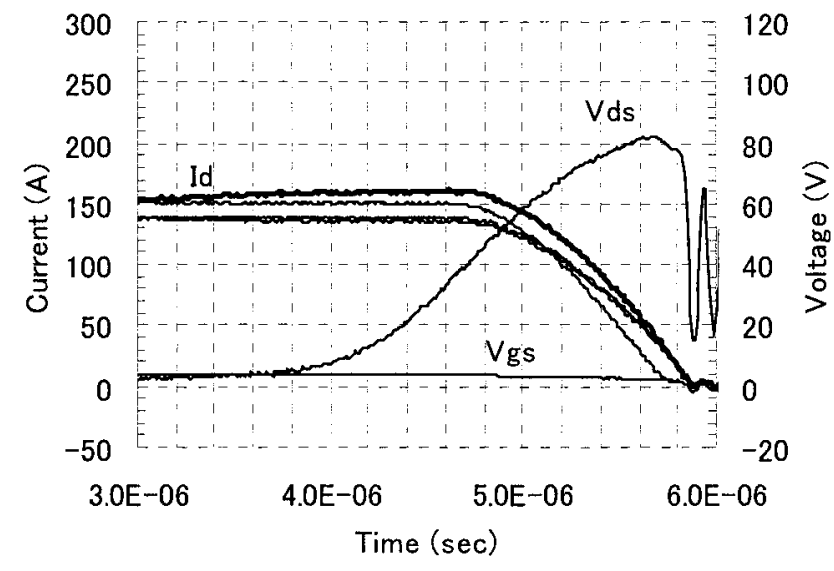

図 12 低速スイッチング時のターンオフ波形

Fig. 12. Turn off waveforms with slow switching.

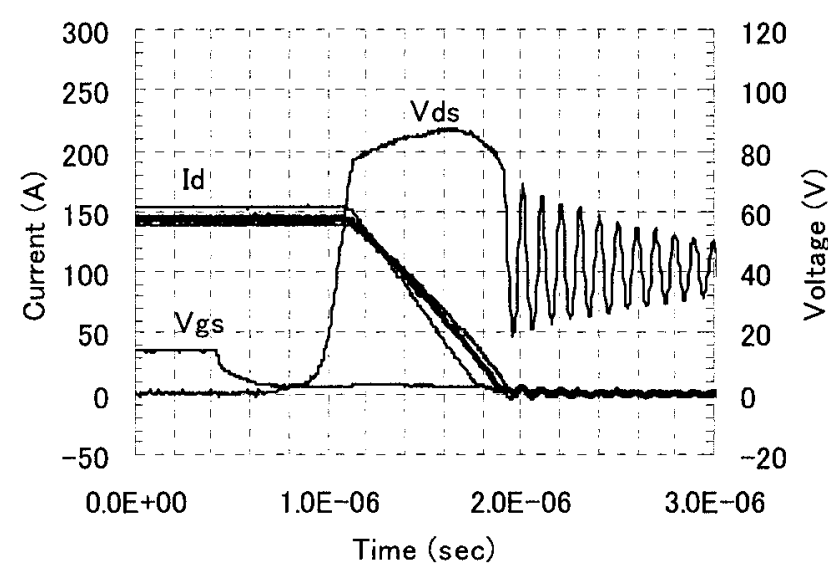

図 13 提案方式でのターンオフ波形

Fig. 13. Turn off waveforms with proposed circuit. 


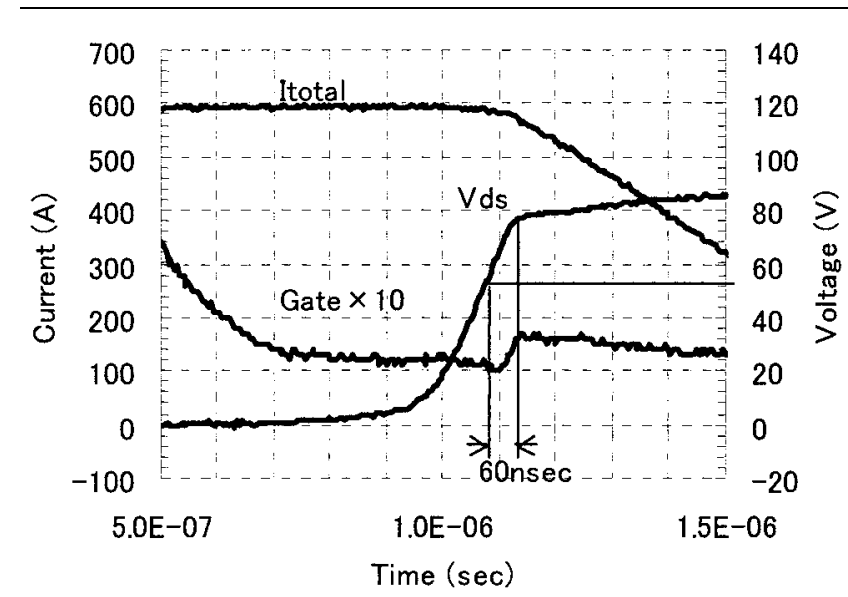

図 14 提案方式でのターンオフ波形 (拡大波形)

Fig. 14. Enlargement waveforms with proposed circuit.

電圧を検知してから損失均等分散回路が動作し，Q2 が才

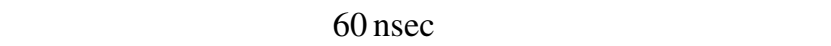
が可能であった。この回路応答時間が速いほど $\mathrm{R}_{\mathrm{G} 2}$ を小さ な值に設定できるため, ドレイン電圧が電源電圧まで上昇 し，電流の転流が開始するまでの期間での損失が小さくな り，ターンオフ損失を低減することが可能となる。

〈 4. 4 損失均等分散回路の動作安定性 損失均等分散 回路では, サージ電圧検出にツェナーダイオードを使用し ている。ツェナーダイオードには浮遊容量が存在するため， MOSFET のドレイン電圧が上昇する時に, 変位電流が流れ る。この変位電流はサージ電圧検出信号と同極性となるた め，トランジスタ Q4 を誤動作させる可能性がある。光の ため，損失均等分散回路を安定動作させるには，サージ電 圧検出電流と変位電流の $\mathrm{S} / \mathrm{N}$ 比を高くする必要がある。

变位電流はサージ電圧検出電流の直前に発生することか ら，損失均等分散回路では，変位電流をトランジスタ $\mathrm{Q} 4 の$ 浮遊容量の予備充電用信号として利用することで, 損失均等 分散回路の高速化を図っている。具体的には，トランジス タ Q4 のベースーエミッタ間電圧か変位電流通電時は $0.5 \sim$ $0.6 \mathrm{~V}$, サージ電圧検出信号検知時には $0.7 \mathrm{~V}$ 以上となるよ うに，回路パラメータを設定した。

图 15 に, ターンオフ時のトランジスタ Q4 のベース電 流，コレクタ電流を示す。トランジスタ Q4 のベース電流 は, ツェナーダイオードの变位電流て約 $2 \mathrm{~mA}$,サージ電圧 検出時で約 $6 \mathrm{~mA}$ と $\mathrm{S} / \mathrm{N}$ 比は約 3 倍確保されているため， 損失均等分散回路の確実な動作が行われている。また，変 位電流によって Q4 を閾値電圧以下の設定電圧に予備充電 させているため, サージ電圧検出後のトランジスタ Q4 の 高速動作が可能となっている。

〈4 5〉スイッチング損失比較图 16 に,各方式のター ンオフ損失を示す。図には, 同一ロット内の MOSFET を 使用した時に，素子特性ばらつき (アバランシェ電圧，し きい值電圧) によって, 最も損失が大きくなる MOSFET の ターンオフ損失と, 4 素子分の全ターンオフ損失を示して いる。この時の特定素子への損失集中は, アバランシェ電

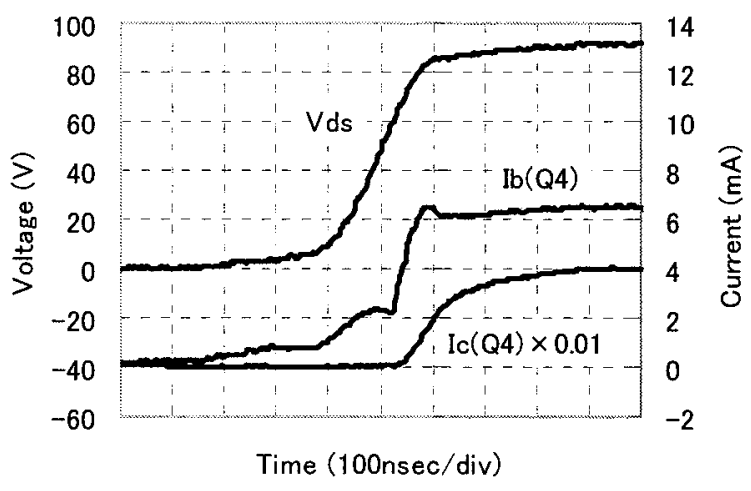

図 15 提案方式でのターンオフ波形 (拡大波形)

Fig. 15. Enlargement waveforms with proposed circuit.

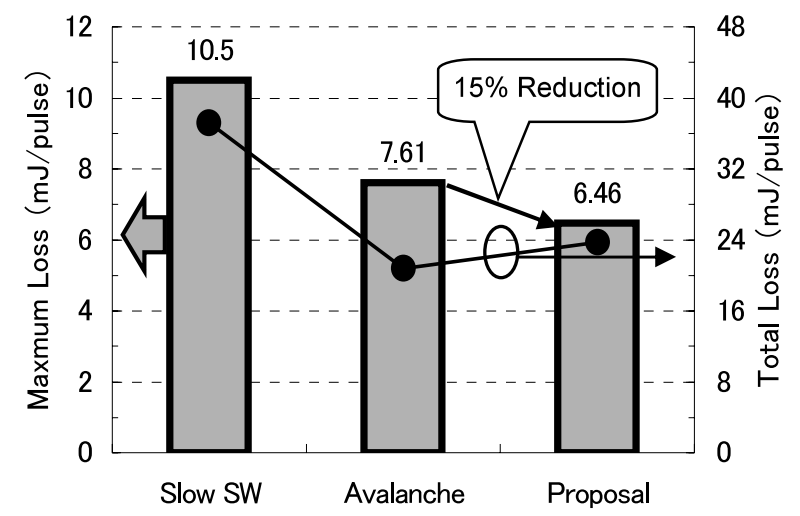

図 16 各方式の損失比較

Fig. 16. Comparison of switching loss of all methods.

圧ばらつき時が約 150\%であるのに対し，本回路方式では 約 110\%に低減されており，損失均等化が可能であること を確認できた。

本回路方式での全ターンオフ損失は, クランプ電圧をア バランシェ電圧以下に下げたこと，損失均等分散回路の応 答時間（約 $60 \mathrm{nsec}$ ）を確保したことにより，アバランシェ 動作させたときに比べ $10 \%$ 強増加している。しかし，アバ ランシェ動作時のような特定素子への損失集中がほとんど ないため，損失集中素子のターンオフ損失はアバランシェ 動作時の $7.6(\mathrm{~mJ} / \mathrm{pulse})$ に対し, 6.46 ( $\mathrm{mJ} / \mathrm{pulse})$ となり， 約 15\%低減することが可能となった。なお,Slow Swiching 時での全ターンオフ損失はアバランシェ時の $180 \%$ となる ため，損失集中素子のターンオフ損失は $10.5(\mathrm{~mJ} / \mathrm{pulse})$ と 最も大きい值となった。

5. まとめ

低電圧 $\cdot$ 大電流定格の電力変換装置ではターンオフ損失 の比率が高いため, パワーMOSFET を多並列接続する場 合, ターンオフ損失の均等化が重要である。ターンオフ時 のサージエネルギーをパワーMOSFET のアバランシェ特 性で消費させると，アバランシェ電圧の低い素子に損失が 集中し, 全ての素子能力を最大限に利用する事ができない。 本論文では, アバランシェ電圧ばらつきによる損失集中 
のシミュレーションを行い, アバランシェ電圧ばらつきに よって素子温度が上昇することを示した。また，MOSFET のドレインーソース間電圧を検知し , サージエネルギーを MOSFET のチャネル抵抗で消費させることで, サージエ ネルギーを多並列接続された MOSFET に均等分散できる ゲート駆動回路方式を提案した。

MOSFET の 4 並列条件で実測評価した結果，本方式によ り，特定の素子への損失集中度を $150 \%$ から $110 \%$ に低減で き，損失均等化が可能であることを示した。また，本方式 は $60 \mathrm{nsec}$ の高速動作が可能であるため, スイッチング時 間の増加はほとんどなく，弚の結果，損失集中素子の損失 を約 15\%低減できることを示した。

(平成 16 年 1 月 15 日受付, 平成 16 年 4 月 16 日再受付)

$$
\text { 文献 }
$$

(1) T. Uesugi: "Prediction for Avalanche Induced Failure of Power MOSFET", R\&D Review of Toyota CRDL, Vol.31, No.1 (1996-3)

(2) A. Vetter, G. Ferber, and R. Schlorke: "High current module for the automobile industry", Power Conversion Proceedings, pp.299-301 (1999-6)

(3) A.F.J. Murray, P. Wood, N. Keskar, J. Chen, and A. Guerra: "A 42 V Inverter/Rectifier for ISA using Discrete Semiconductor Components", Future Transportation Technology Conference (2001-8)

奥 田達也

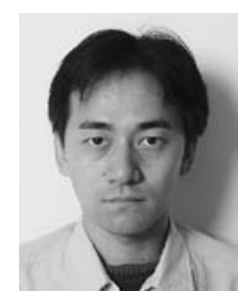

(正員) 1973 年 6 月 7 日生。1998 年 3 月東京工 業大学大学院理工学研究科電気・電子工学専攻修 士課程修了。同年 4 月三菱電機 (株) 入社, 現在 に至る。主として,パワーエレクトロニクス装置 の研究・開発に従事。
角 田義 一 (非会員) 1971 年 8 月 9 日生。1990 年 3 月和歌

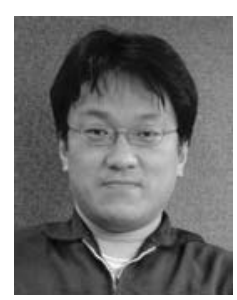
山工業高等学校電子機械科卒業。同年, 三菱電機 (株) 入社。以来, 半導体スイッチ, パルスパワー 装置, PDP 装置の開発, $42 \mathrm{~V}$ 電力機器の開発に 従事。

浅 井 孝 公 (非会員) 1974 年 8 月 5 日生。 2000 年 3 月同志

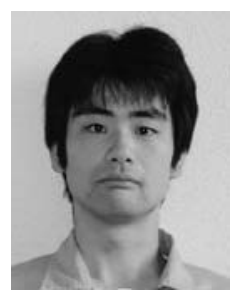
社大学大学院工学研究科 (電気工学専攻) 卒業。 同年三菱電機エンジニアリング (株) 入社。主と して HEV 用インバータユニットの開発に従事。

浦 壁 隆 浩 (非会員) 1964 年 4 月 16 日生。1988 年 3 月慶

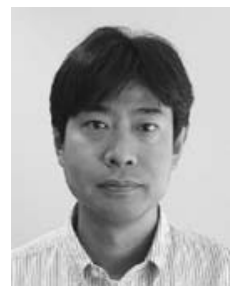
応義塾大学計測工学科卒業。同年三菱電機 (株) 入社。以来, 平面形蛍光ランプ, PDP, 低温 polySiTFT-LCD ドライバ, 配列形放電ディスプレイ, HID ランプ点灯装置の開発に従事。 